\title{
Front Matter: Volume 9462
}

, "Front Matter: Volume 9462," Proc. SPIE 9462, Passive and Active Millimeter-Wave Imaging XVIII, 946201 (22 June 2015); doi:

$10.1117 / 12.2201100$

SPIE. Event: SPIE Defense + Security, 2015, Baltimore, MD, United States 


\section{PROCEEDINGS OF SPIE}

\section{Passive and Active Millimeter- Wave Imaging XVIII}

David A. Wikner

Arttu R. Luukanen

Editors

23 April 2015

Baltimore, Maryland, United States

Sponsored and Published by

SPIE 
The papers included in this volume were part of the technical conference cited on the cover and title page. Papers were selected and subject to review by the editors and conference program committee. Some conference presentations may not be available for publication. The papers published in these proceedings reflect the work and thoughts of the authors and are published herein as submitted. The publisher is not responsible for the validity of the information or for any outcomes resulting from reliance thereon.

Please use the following format to cite material from this book:

Author(s), "Title of Paper," in Passive and Active Millimeter-Wave Imaging XVIII, edited by

David A. Wikner, Arttu R. Luukanen, Proceedings of SPIE Vol. 9462 (SPIE, Bellingham, WA, 2015) Article CID Number.

ISSN: 0277-786X

ISBN: 9781628415780

Published by

SPIE

P.O. Box 10, Bellingham, Washington 98227-0010 USA

Telephone +1 3606763290 (Pacific Time) · Fax +1 3606471445

SPIE.org

Copyright (C) 2015, Society of Photo-Optical Instrumentation Engineers.

Copying of material in this book for internal or personal use, or for the internal or personal use of specific clients, beyond the fair use provisions granted by the U.S. Copyright Law is authorized by SPIE subject to payment of copying fees. The Transactional Reporting Service base fee for this volume is $\$ 18.00$ per article (or portion thereof), which should be paid directly to the Copyright Clearance Center (CCC), 222 Rosewood Drive, Danvers, MA 01923. Payment may also be made electronically through CCC Online at copyright.com. Other copying for republication, resale, advertising or promotion, or any form of systematic or multiple reproduction of any material in this book is prohibited except with permission in writing from the publisher. The CCC fee code is 0277-786X/15/\$18.00.

Printed in the United States of America.

Publication of record for individual papers is online in the SPIE Digital Library.

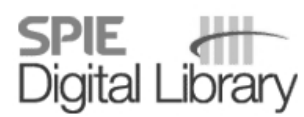

SPIEDigitallibrary.org

Paper Numbering: Proceedings of SPIE follow an e-First publication model, with papers published first online and then in print. Papers are published as they are submitted and meet publication criteria. A unique citation identifier (CID) number is assigned to each article at the time of the first publication. Utilization of CIDs allows articles to be fully citable as soon as they are published online, and connects the same identifier to all online, print, and electronic versions of the publication. SPIE uses a six-digit CID article numbering system in which:

- The first four digits correspond to the SPIE volume number.

- The last two digits indicate publication order within the volume using a Base 36 numbering

system employing both numerals and letters. These two-number sets start with 00, 01, 02, 03, 04, $05,06,07,08,09,0 A, 0 B \ldots 0 Z$, followed by 10-1Z, 20-2Z, etc.

The CID Number appears on each page of the manuscript. The complete citation is used on the first page, and an abbreviated version on subsequent pages. 


\title{
Contents
}

\author{
$\checkmark$ Authors \\ vii Conference Committee
}

\section{SESSION 1 SYSTEMS I}

946204 Concealed object stand-off real time imaging for security: CONSORTIS [9462-4]

946205 Toward a real time stand-off submillimeter-wave imaging system with large field of view: quasi-optical system design considerations [9462-5]

946206 Noise analysis for near field 3D FM-CW radar imaging systems [9462-6]

SESSION 2 SYSTEMS II

946209 Video rate passive millimeter-wave imager utilizing optical upconversion with improved size, weight, and power [9462-9]

9462 0A Optical network connected multi-channel $96 \mathrm{GHz}$ band distributed radar system [9462-10]

\section{SESSION 3 SYSTEMS III}

9462 OB Some opinion about matrix terahertz imaging system based on Josephson junctions [9462-11]

\section{SESSION 4 PHENOMENOLOGY}

$94620 \mathrm{D}$ Toward the development of an image quality tool for active millimeter wave imaging systems [9462-13]

9462 OF Identifying explosives by dielectric properties obtained through wide band millimeterwave illumination [9462-15]

$94620 \mathrm{G}$ Summary and analysis of $216 \mathrm{GHz}$ polarimetric measurements of in-situ rain [9462-16]

$9462 \mathrm{OH} \quad$ Electromagnetic scattering from dielectric surfaces at millimeter wave and terahertz frequencies [9462-17]

\section{SESSION 5 IMAGE PROCESSING}

$94620 \mathrm{~J}$ Automatic detection of hidden threats in the TeraSCREEN passive millimeter-wave imaging subsystem [9462-19] 
9462 OK Feasibility of radon projection acquisition for compressive imaging in $\mathrm{MMW}$ region based new video rate $16 \times 16$ GDD FPA camera [9462-20]

$9462 \mathrm{OL} \quad$ Real time image processing for passive $\mathrm{mmW}$ imagery [9462-21] 


\section{Authors}

Numbers in the index correspond to the last two digits of the six-digit citation identifier (CID) article numbering system used in Proceedings of SPIE. The first four digits reflect the volume number. Base 36 numbering is employed for the last two digits and indicates the order of articles within the volume. Numbers start with 00, 01, 02, 03, 04, 05, 06, 07, 08, 09, 0A, 0B...0Z, followed by 10-1Z, 20-2Z, etc.

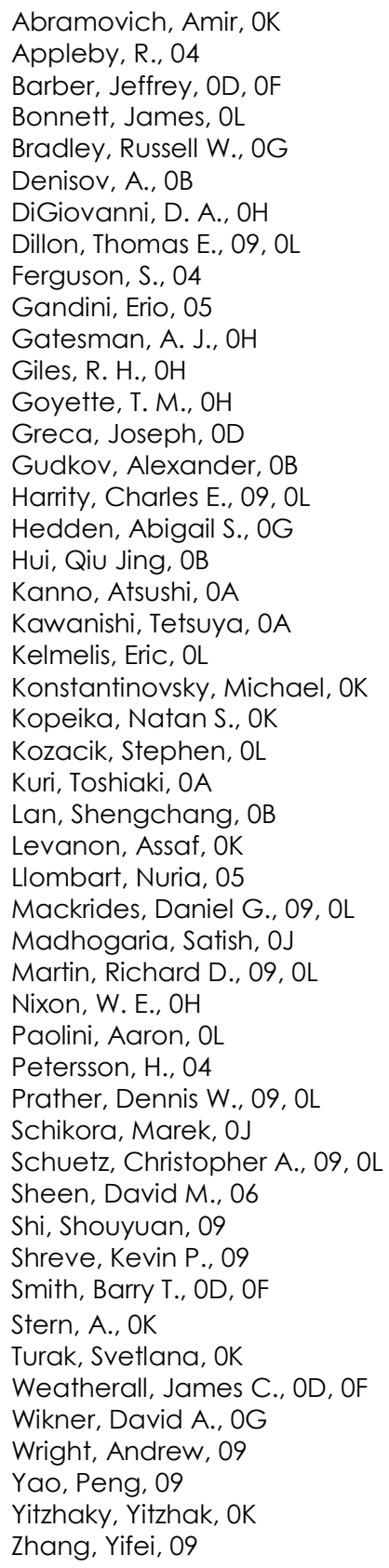


Proc. of SPIE Vol. $9462946201-6$

Downloaded From: https://www.spiedigitallibrary.org/conference-proceedings-of-spie on 26 Apr 2023 Terms of Use: https://www.spiedigitallibrary.org/terms-of-use 


\section{Conference Committee}

Symposium Chair

Nils R. Sandell Jr., Strategic Technology Office, DARPA (United States)

Symposium Co-chair

David A. Logan, BAE Systems (United States)

Conference Chairs

David A. Wikner, U.S. Army Research Laboratory (United States)

Arttu R. Luukanen, Asqella Corporation (Finland)

Conference Program Committee

Roger Appleby, Queen's University Belfast (United Kingdom)

Erich N. Grossman, National Institute of Standards and Technology

(United States)

Christopher A. Martin, Trex Enterprises Corporation (United States)

Duncan A. Robertson, University of St. Andrews (United Kingdom)

Bruce Wallace, Defense Advanced Research Projects Agency

(United States)

Session Chairs

1 Systems I

Arttu R. Luukanen, Asqella Corporation (Finland)

2 Systems II

David A. Wikner, U.S. Army Research Laboratory (United States)

3 Systems III

David A. Wikner, U.S. Army Research Laboratory (United States)

4 Phenomenology

Roger Appleby, Queen's University Belfast (United Kingdom)

5 Image Processing

Arttu R. Luukanen, Asqella Corporation (Finland) 
Proc. of SPIE Vol. $9462946201-8$

Downloaded From: https://www.spiedigitallibrary.org/conference-proceedings-of-spie on 26 Apr 2023 Terms of Use: https://www.spiedigitallibrary.org/terms-of-use 